\title{
GREEN SYNTHESIS OF INORGANIC NANOPARTICLES AS THERAPEUTIC PROPOSALS FOR CANCER: A REVIEW ${ }^{1}$
}

\author{
SÍNTESE VERDE DE NANOPARTÍCULAS INORGÂNICAS COMO \\ PROPOSTAS TERAPÊUTICAS PARA O CÂNCER: UMA REVISÃO
}

\author{
Samantha Nunes de Godoi' ${ }^{2}$, Solange Binotto Fagan ${ }^{3}$, \\ Patrícia Gomes $^{4}$ e Aline Ferreira Ourique ${ }^{5}$
}

\begin{abstract}
Currently, the deliberate use of medications is discussed due to the resistance that patients have shown in relation to conventional treatments, addiction processes and often intoxication due to self-dosing. Seeking to minimize this tendency, many compounds of natural origin have been studied in an attempt to less toxic and less costly therapies, due to the fact that they are compounds present in nature in abundance. Obtained from natural compounds, extracts from plants have gained space in studies that seek new potential pharmacological applications. Nanosystems are known for their ability to add different potentials to compounds, such as increasing stability, protecting from degradation and minimizing possible adverse effects. Inorganic nanoparticles have gained space in the focus of cancer treatment, however, toxicological and biopersistent factors have caused discussions and led to the search for alternatives. Thus, the "green synthesis" arises, where natural products and other compounds, added to the production of this type of nanostructured systems would have the potential to add biocompatibility to nanoparticles, thus making possible therapeutics. In this context, a review study was carried out, using the Scopus database, which mentioned the application of extracts linked to the production of inorganic nanoparticles, in order to propose new treatments for cancer. As a result, we can observe that the use of inorganic nanoparticles production methods involving natural compounds is growing. This study aimed to encourage research that emphasizes the use of compounds of natural origin linked with nanotechnology, envisioning innovative and effective treatments against cancer.
\end{abstract}

Keywords: plant extracts, nanotechnology, antitumor activity.

\section{RESUMO}

Atualmente discute-se o uso deliberado de medicamentos devido a resistência que os pacientes têm apresentado frente a tratamentos convencionais, processos de dependência e muitas vezes intoxicação por auto-dosagem. Buscando minimizar essa tendência, muitos compostos de origem natural vêm sendo estudados na tentativa de terapias menos tóxicas e de menor custo, pelo fato de serem compostos presentes na natureza em abundância. Obtidos a partir de compostos naturais, os extratos provenientes de plantas têm conquistado espaço em estudos que buscam novas potenciais aplicabilidades farmacológicas. Os nanossistemas são

${ }^{1}$ Article prepared in the discipline of the doctorate.

${ }^{2}$ Doctor student of the Programa de Pós-graduação em Nanociências - Universidade Franciscana. E-mail: sam.nunes.godoi@ gmail.com

${ }^{3}$ Collaborator. Teacher of the Programa de Pós-graduação em Nanociências - Universidade Franciscana. E-mail: solange. fagan@gmail.com

${ }^{4}$ Collaborator. Teacher of the Programa de Pós-graduação em Nanociências - Universidade Franciscana. E-mail: patriciagomes@, ufn.edu.br

${ }^{5}$ Advisor. Teacher of the Programa de Pós-graduação em Nanociências - Universidade Franciscana. E-mail: alineourique@ gmail.com 
conhecidos pela capacidade de agregar diversas potencialidades a compostos, como aumentar a estabilidade, proteger de degradação e ainda minimizar possíveis efeitos adversos. As nanopartículas inorgânicas têm ganhado espaço no enfoque do tratamento do câncer, no entanto, fatores toxicológicos e biopersistentes tem causado discussões e ocasionado a busca por alternativas. Assim surge a "síntese verde", onde produtos naturais e outros compostos, agregados a produção dessa modalidade de sistemas nanoestruturados teriam o potencial de agregar biocompatibilidade às nanopartículas viabilizando assim possíveis terapêuticas. Nesse contexto, foi realizado um estudo de revisão, utilizando a base de dados Scopus, que fizeram menção à aplicação de extratos vinculados a produção de nanoparticulas inorgânicas, com o intuito de propor novos tratamentos para o câncer. Como resultados podemos observar que o uso de métodos de produção de nanopartículas inorgânicas envolvendo compostos naturais encontra-se em crescimento. Esse estudo teve por objetivo incentivar pesquisas que enfatizem a utilização de compostos de origem natural interligados com a nanotecnologia, vislumbrando tratamentos inovadores e eficazes contra o câncer.

Palavras-chave: extratos vegetais, nanotecnologia, atividade antitumoral.

\section{INTRODUCTION}

Cancer can be defined as an abnormal proliferation of cells within tissues of living organisms (MEDINA CRUZ et al., 2019). It is estimated, for Brazil, that in the 2018-2019 biennium, the occurrence of 600 thousand new cases of cancer, for each year (INCA, 2017). In addition, another concern that is intertwined with a high incidence of cancer is the resistance that tumor cells have developed against chemotherapy commonly used in the therapy of the disease (MEDINA CRUZ et al., 2019).

Plants are an important source of bioactive substances and natural compounds (BHOURI et al., 2018). Most plant-derived compounds have direct or indirect therapeutic effects and are widely studied as medicinal agents (JAMSHIDI-KIA et al., 2018). A study by Yu et al. (2020) highlights that natural compounds made up of some specific constituents would be able to induce a process called "programmed necrosis", thus having the ability to lead malignant cells to cell death, enabling new therapeutic horizons for cancer using natural compounds.

Nanotechnology studies the control of matter at the atomic and molecular scale, triggering new properties (AL-RADADI, 2018). It appeared in the 1980s and, shortly afterwards, being applied to medicine, it caused the origin of nanomedicine (MEDINA CRUZ et al., 2019). Nanotechnology has many benefits in its handling, such as: several forms of encapsulation, specific functionalization of surfaces and nanoparticles designed for the administration of chemotherapeutic agents aiming at lower toxicity (CHANDRASEKARAN et al., 2016).

Inorganic nanoparticles are among the most explored nanosystems in commercial products, being based on metal - (Ag, Ti, Zn, Au), carbon - (carbon nanotubes, fullerenes, graphene) and silicon (silicon and silica) are among the most popular nanoparticles (CAO et al., 2017).

The biocompatibility factor is one of the main concerns when it comes to inorganic nanoparticles for applications where they will be used as a drug delivery system (POOJA et al., 2015). In an 
attempt to circumvent these issues, natural compounds such as sugars and plant extracts have been added to the production of inorganic nanoparticles showing the potential to add biocompatibility to these systems through this approach called "green synthesis" (POOJA et al., 2015).

This study aims to make a bibliographic review on extracts used for the "green synthesis" of different modalities of inorganic nanoparticles and that propose innovative therapies for the treatment of cancer.

\section{MATERIALS AND METHODS}

An updated review of scientific literature indexed in the $S$ copus $^{6}$ database was carried out, which currently consists of 3,850 journals from different areas of knowledge, until the period of July 31, 2019. Three restrictions were made during the research, filtered the search was made only by the format of research articles, final version of publication and in the English language. Three descriptors were used for the bibliographic survey: "human cancer and inorganic nanoparticles" and later "green synthesis and extracts" properly grouped. A concise analysis of the articles was carried out, addressing their relevant aspects for the preparation of this review study.

\section{EVALUATION OF ARTICLES}

A search was carried out in the Scopus database, where through the descriptor "human cancer and inorganic nanoparticles" 578 results were found, with articles published over a period of 17 years, between 2003 and 2019, including numerous journals.

Subsequently, the second descriptor "green synthesis and extracts" was added, demonstrating the decay of results for 28 articles published over 9 years (2010-2019).

After the application of the three restriction criteria, the search was completed with 10 research articles, in the final version of publication, in english published in the period between the years 2013-2019 to continue the analyzes.

\section{EXCLUSION CRITERIA}

The criteria for selecting articles for this study occurred as follows, to be considered suitable for the review, they had to:

- Present any proposal related to cancer;

- Make use of some inorganic nanoparticle;

- Use extract for "green synthesis" of nanoparticles;

\footnotetext{
${ }^{6}$ Www.scopus.com
} 
Articles that did not meet these criteria were excluded from this review study. The analysis was carried out based on the summary of the articles and, in case of doubt, a study as a whole was consulted.

\section{RESULTS AND DISCUSSIONS}

\section{DESCRIPTORS ANALYSIS}

After searching the database, using the descriptor "human cancer and inorganic nanoparticles", the results shown in Figure 1 were found below.

Figure 1 - Number of articles published in 17 years of research (2003-2019).

\section{Number of Publications}

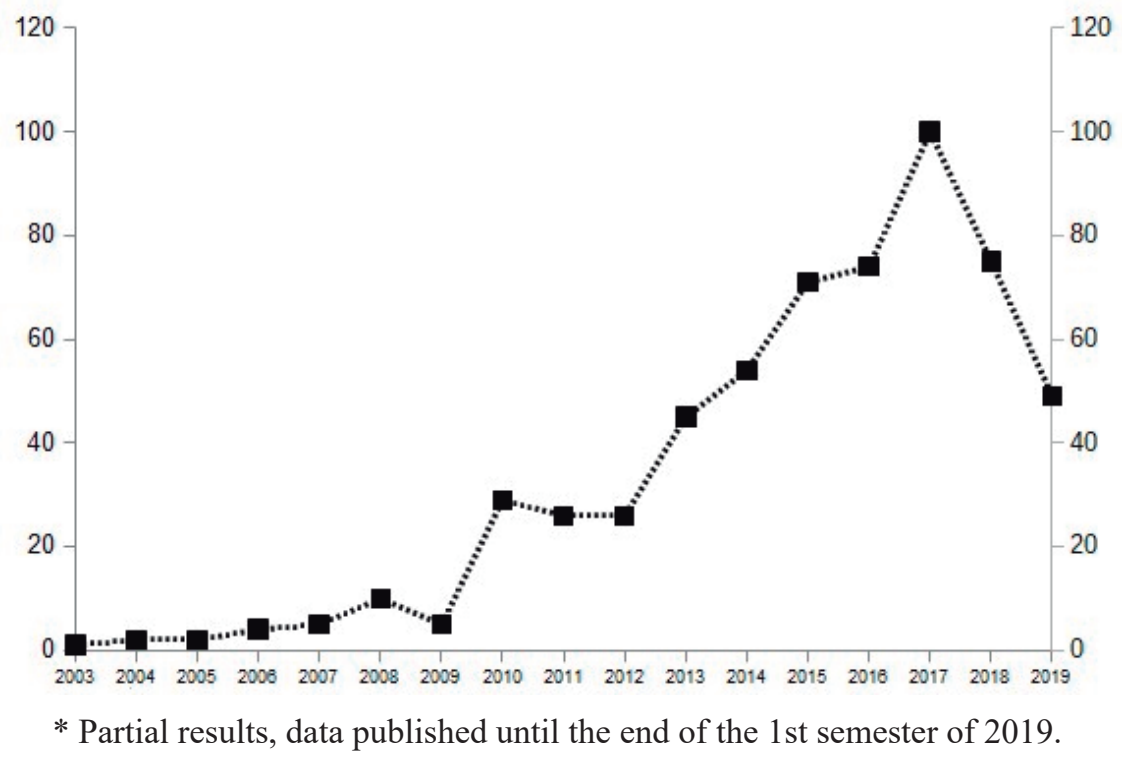

Source: Elaborated by the author based on the results obtained from the Scopus database.

Table 1 below presents a list of the 10 journals that most publish studies in this area, data based on the results found from the descriptor "human cancer and inorganic nanoparticles".

Later, when the second descriptor "green synthesis and extracts" was added and the restriction criteria were applied, the results are shown in Figure 2, which shows the number of publications on the subject over the course of 7 years (2013-2019). 
Table 1 - Ranking of journals that publish the most on the theme.

\begin{tabular}{clc}
\hline Classification & \multicolumn{1}{c}{ Periodic } & $\begin{array}{c}\text { Impact } \\
\text { factor }\end{array}$ \\
\hline $1^{\circ}$ & Nanomedicine & 6.500 \\
\hline $2^{\circ}$ & Biomaterials & 10.273 \\
\hline $3^{\circ}$ & Journal Of Controlled Release & 7.901 \\
\hline $4^{\circ}$ & ACS Nano & 13.903 \\
\hline $5^{\circ}$ & ACS Applied Materials and Interfaces & 8.456 \\
\hline $6^{\circ}$ & Nanomedicine & 5.005 \\
$7^{\circ}$ & International Journal Of Molecular Sciences & 4.183 \\
\hline $8^{\circ}$ & Advanced Drug Delivery Reviews & 15.519 \\
$9^{\circ}$ & Colloids and Surfaces B: Biointerfaces & 3.973 \\
\hline $10^{\circ}$ & International Journal of Nanomedicine & 4.471 \\
\hline
\end{tabular}

Source: Prepared by the authors based on the results obtained in the Scopus database.

Figure 2 - Number of publications on the subject in the last 7 years (2013-2019).

\section{Number of Publications}

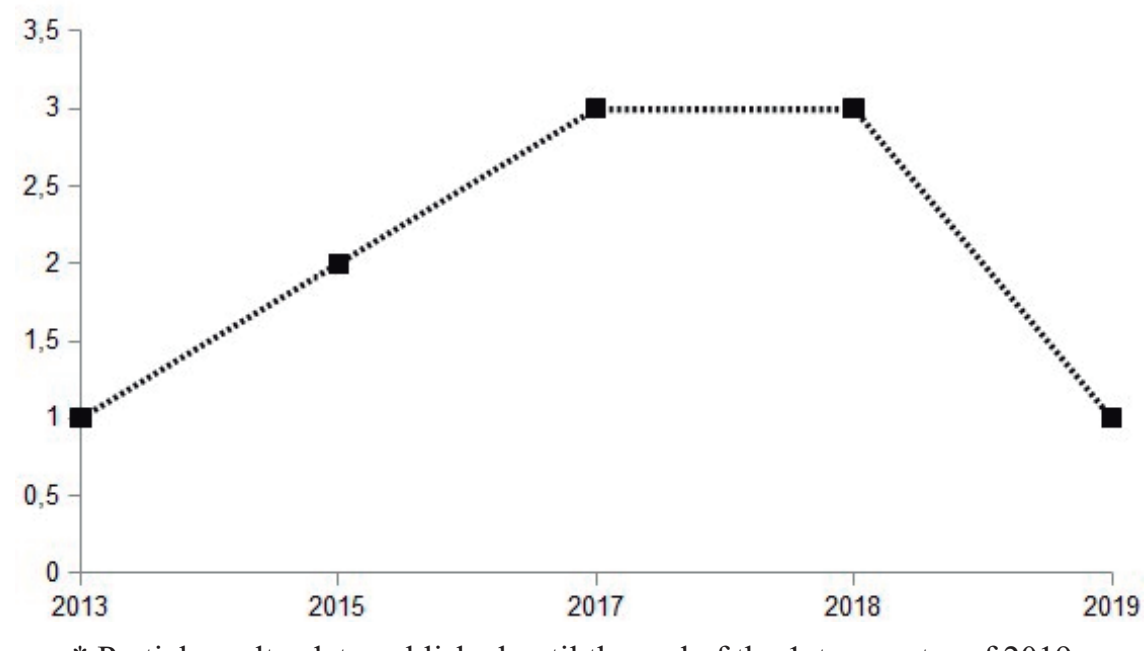

* Partial results, data published until the end of the 1st semester of 2019.

Source: Prepared by the authors based on the results obtained in the Scopus database.

Among the journals to which they presented publications from the secondary descriptor "green synthesis and extracts" are shown in Table 2, where the year of publication of the article is described, the journal where the study is published, the nanosystems used/proposed in the study and finally the work reference. 
Table 2 - List of articles found, author of the article, nanosystem used and respective year of publication.

\begin{tabular}{|c|c|c|c|}
\hline Year of publication & Journal & Nanosystems & Reference \\
\hline 2019 & Nanotechnology & $\alpha-\mathrm{Fe} 2 \mathrm{O} 3 / \mathrm{NiO}$ nanocomposite & Bhushan et al. (2019) \\
\hline \multirow{3}{*}{2018} & Environmental Toxicology & $\mathrm{Fe}_{3} \mathrm{O}_{4}-\mathrm{TiO}_{2}$ nanoparticles & Su et al. (2018) \\
\hline & Nanomedicine & Inorganic nanocomposite & Orsi et al. (2018) \\
\hline & $\begin{array}{c}\text { Journal of Photochemistry and } \\
\text { Photobiology B: Biology }\end{array}$ & Zinc oxide nanoparticles & Zhao et al. (2018) \\
\hline \multirow{3}{*}{2017} & Journal of Biomedical & Text unavailable & Wang et al. (2017) \\
\hline & $\begin{array}{l}\text { Nanotechnology } \\
\text { Phytochemistry Reviews }\end{array}$ & Inorganic nanoparticles in general & Cao et al. (2017) \\
\hline & RSC Advances & Silver nanoparticles & Kalaiyarasan et al. (2017) \\
\hline \multirow{2}{*}{2015} & $\begin{array}{c}\text { International Journal of } \\
\text { Biological Macromolecules }\end{array}$ & Gold nanoparticles & Pooja et al. (2015) \\
\hline & $\begin{array}{c}\text { Journal of Biomaterials } \\
\text { Applications }\end{array}$ & Gold nanoparticles & Manjumeen et al. (2015) \\
\hline 2013 & $\begin{array}{c}\text { Drug Delivery and } \\
\text { Translational Research }\end{array}$ & Inorganic nanoparticles in general & Pranatharthiharan et al. (2013) \\
\hline
\end{tabular}

Source: Prepared by the authors based on the results obtained in the Scopus database and reading of the articles.

\section{ANALYSIS OF ARTICLES}

After analyzing the articles previously mentioned and submitting each one to the study's exclusion criteria, results were obtained where the use of inorganic nanoparticles production methods involving natural compounds demonstrates a comprehensive and growing form. Aiming at the use of a natural compound as a production agent of the nanosystems to which they were then studied for cancer therapy.

The works found by the secondary descriptor and which did not mention promising therapies for cancer were excluded from the discussion due to the theme not including the review article.

Of the authors found, eight studies make no direct mention of the use of natural compounds for the production of inorganic nanoparticles. Then we made a brief account of these researches, which also require relevant approaches for cancer research.

The first study published by Pranatharthiharan et al. (2013), it is a review of nanovectors in the delivery of nucleic acids. The article makes reference to inorganic nanovectors, which in turn, have gained prominence in studies due to their microbial resistance, low toxicity, satisfactory stability and may still be subject to functionalization. The authors state that, although extremely promising, analyzes on inorganic nanovectors are still limited, however third authors cited in the text report their promising action against cancer. This review covers, among other approaches, specific properties and types of inorganic nanovectors, their methods of preparation and applications as therapeutic, diagnostic and teranostic agents. As perspectives, the authors bring that aspects of the safety profile of nanovectors as well as the environmental impact in the use / handling of these systems must be further investigated, aiming at future biodegradable and biodegradable products, thus minimizing possible toxicity and enabling in vivo model tests. 
The article published by Orsi et al. (2018), aims at the synthesis and characterization of an inorganic nanocomposite with applicability in self-illuminated photodynamic therapy against cancer, considering the combination of radiotherapy and photodynamic therapy enabled by self-illuminated photodynamic therapy allows localized treatment of deep tumors, with greater efficiency, reduced doses of radiographs and less side effects in healthy tissues. The nanocomposite is composed of a combination of $\mathrm{CeF}_{3}$ and $\mathrm{ZnO}$, where $\mathrm{CeF}_{3}$ absorbs 6-MeV x-rays and activates the $\mathrm{ZnO}$ photoensitizer; this system was characterized using transmission electron microscopy (TEM), TEM scanning, energy dispersive X-ray spectrometry and fluorescence spectroscopy. Subsequently, this system was applied to human lung adenocarcinoma cells - A549 (standard model for this type of evaluation), the evaluation took place using the following methodologies: fluorescence spectroscopy, cytofluorimetry, viability tests, clonogenic tests and progression tests of the cell cycle. As a result, the authors found that when internalized in A549 cells for 24 hours, the NCs block the cell cycle before mitosis in the absence of irradiation, effectively reducing the viability of pathological cells without inducing apoptosis or necrosis and how they intend to focus on a strategy coating of the nanocomposite, with a view to seeking a way for the recognition and elimination by the immune system, envisioning studies in vivo.

In the work carried out by Su et al. (2018) the objective was to evaluate toxicity and molecular mechanisms through different methods of $\mathrm{Fe}_{3} \mathrm{O}_{4}-\mathrm{TiO}_{2}$ nanoparticles and $\mathrm{TiO}_{2}$ nanoparticles against human liver cells (HL-7702). The authors highlight as results that both $\mathrm{Fe}_{3} \mathrm{O}_{4}-\mathrm{TiO}_{2}$ and $\mathrm{TiO}_{2}$ nanoparticles decreased cell viability and ATP levels when exposed to cells, but increased the generation of malonaldehyde and the generation of reactive oxygen species (ROS). In addition, results suggest that both $\mathrm{Fe}_{3} \mathrm{O}_{4}-\mathrm{TiO}_{2}$ nanoparticles and $\mathrm{TiO}_{2}$ nanoparticles could induce oxidative stress and could induce an in vitro carcinogenic effect at higher concentrations. The authors highlight the importance of complementary studies to elucidate the mechanisms of toxicity at higher concentrations of these systems.

After analysis, the studies that were selected for discussion on the central theme of this study, were 3 articles, to which they are: Zhao et al. (2018), Manjumeen et al. (2015) and Pooja et al. (2015).

In the study by Zhao et al. (2018), Anacardium occidentale leaf extract was used in the "green synthesis" of zinc oxide nanoparticles. In the present study, the authors report the production of the extract, the biosynthesis of the nanoparticles, their characterization (diffractometer, spectrophotometer, spectroscopy, transmission electron microscopy, among others) and finally, the cell culture of normal human fibroblast strains (Hu02) and of human pancreatic cancer cells (Panc-1 and AsPC-1) with cell viability assessment. The results obtained in the characterization of the UV-Vis spectrophotometer demonstrated a range of $375 \mathrm{~nm}$, which indicates the formation of zinc oxide nanoparticles using plant extract; in the X-ray diffraction analysis, the crystalline nature of the synthesized nanosystem was confirmed and, in the absence of additional peaks in this analysis, the purity of the nanoparticles is adequate; from the images obtained by transmission electron microscopy, the presence of hexagonal nanoparticles and an average size of $33 \mathrm{~nm}$ can be confirmed; through 
spectroscopy analysis, the presence of signals corresponding to elemental zinc and oxygen is verified, confirming the formation of zinc oxide nanoparticles. The second part of the study, which consisted of analyzing the cytotoxicity of zinc oxide nanoparticles from the feasibility study in the pancreatic cancer lineage, demonstrated that NPsZnO caused a significant growth inhibition for cancer cells in a concentration-dependent manner. The IC50 values for Panc-1 and AsPC-1 cells after $24 \mathrm{~h}$ are $40 \pm 5.6$ $\mu \mathrm{M}$ and $30 \pm 4.6 \mu \mathrm{M}$, indicating that NPsZnO are more effective for AsPC-1 cells when compared to Panc- 1. Therefore, the concentration of $40 \mu \mathrm{M}$ and $30 \mu \mathrm{M}$ of NPsZnO was considered for its use in in vivo systems in Panc-1 and AsPC-1 cells, respectively. The authors conclude that the cytotoxicity of NPsZnO observed in pancreatic cancer cells is considerably higher when compared to the cytotoxicity caused in normal fibroblast cells.

And the study by Manjumeen et al. (2015), the aqueous extract of Couroupita guianensis was linked to the production of gold nanoparticles through "green synthesis". The study steps consist of preparing the extract, linking it to the production of gold nanoparticles and their characterization, production of nanofibers by the electrospinning process and their characterization. They were evaluated for their antibacterial and antifungal activity using the zone of inhibition method. Biocompatibility and antiproliferative activity in Vero, breast cancer (MCF-7) and cervical cancer (HeLa) strains were also evaluated through MTT assay. As a result of the characterization step of the biosynthesized gold nanoparticles, the UV-Vis spectra showed a well-defined band centered around $526 \mathrm{~nm}$, which is the characteristic of gold nanoparticles and clearly indicates the formation of gold nanoparticles in solution; the average size of the gold nanoparticles was about $15 \mathrm{~nm}$; the crystalline nature of gold nanoparticles has been confirmed by X-ray diffraction analysis. From the evaluation of biocompatibility and antiproliferative activity by different strains, the Vero strain demonstrated a maximum percentage of viability ( $90 \%$ ) at the end of 72 hours of incubation, indicating that the nutrition for cell lines was not harmed by nanofibers, leading to increased cell viability; the presence of gold nanoparticles in the nanofiber showed antiproliferative effects in the cell lines MCF-7 and HeLa. The percentage of proliferation of cell lines MCF 7 and HeLa was only $8 \%$ and 9\%, respectively, at the end of 72 hours of incubation with nanofibers. The proliferation of MCF-7 and HeLa cells decreased in direct proportion to the incubation time of cell lines treated with nanofibers, whereas in cell lines treated only with nanofibers, which did not contain gold nanoparticles, cell proliferation was high.

In the study by Pooja et al. (2015), the researchers obtained a dry exudate from Sterculia urens Roxd called GK, a polysaccharide of a non-toxic nature, low cost and easily available, in addition, it has already been widely used in the pharmaceutical and food industries. In 2013, studies with inorganic copper oxide nanoparticles and silver nanoparticles had already been obtained from GK. Therefore, the objective of this study was to evaluate GK as a potential reducing agent for the production of gold nanoparticles and to investigate these gold nanoparticles linked to gemcitabine hydrochloride (GEM) in the treatment of cancer. The nanoparticles produced with 
GK (GKNP) were characterized by different analytical techniques and tested for the biocompatibility of the nanosystem against normal ovarian cells and lung cancer cells, in addition to studies of hemolytic toxicity. Cytotoxicity studies with human lung cancer cells were performed with GKNP associated with GEM and GEM in its simple form. As a result, the authors stated that the data obtained from the stability studies suggested that the presence of GK molecules on the surface of the nanoparticles not only acted as a reducing agent, but also a capping agent provided colloidal stability to the nanoparticles. GKNP demonstrated high biocompatibility during the studies carried out and GEM-GKNP showed better inhibition of cancer cell growth in the applied tests, when compared to native GEM. The authors conclude the article by highlighting that due to the stability and biocompatibility found during the study, gold nanoparticles linked to GK would be a potential nanosystem in the delivery of anticancer drugs.

In view of the observation and analysis of each article in this study, it appears that among the inorganic nanoparticles associated with gold, it has gained prominence in studies around the world when it comes to the study of therapies for cancer. This statement can be attributed to its various optical-electronic properties, ease of production, possibilities for changes in its surface, low toxicity and biocompatibility; in addition to being able to be produced through physical, chemical and biological aspects (POOJA et al., 2015).

\section{FINAL CONSIDERATIONS}

After the construction of this work, it can be seen that its main contribution was to identify which studies and which are the focus of studies in the nanotechnological area, involving extracts of natural fruitful origin in the production of inorganic nanoparticles related to potential proposals for cancer therapy.

During the construction of this brief review, it became evident that the discussion made here is still grounded and gaining space in cancer research. From the analysis of the studies explained, we can evidence that the research is focused on inorganic nanoparticles, which, due to their history of toxicity and biopersistence, open a wide discussion about their use in several areas. So, the new proposal is to use extracts in the production of these nanoparticles, thus opening a new field of view and making it possible to change the research aspect in relation to this class of nanosystems.

Within the research contemplated in the text of this review, it can be seen that the potential applicability of these "green nanosystems" to different types of cancers is quite expressive, but it should be noted that a deep focus on the nanotoxicological investigation of these nanoparticles is needed, bearing in mind that, they will be envisaged to be administered to very weak and immunodepressed people.

It is extremely important to proceed with innovative and potential investigations in the most diverse areas of knowledge, as well as to search / investigate with responsibility new natural compounds 
that associated with nanotechnology may show unique and promising mechanisms in the fight against the most prevalent disease in the world, cancer.

\section{REFERENCES}

AL-RADADI, N. S. Artichoke (Cynara scolymus L.,) mediated rapid analysis of silver nanoparticles and their utilisation on the cancer cell treatments. Journal of Computational and Theoretical Nanoscience, v. 15, n. 6-7, p. 1818-1829, 2018.

BHOURI, W. et al. P-84 - Biological activities of natural compounds extracted from rhamnus alaternus plant. Free Radical Biology and Medicine, v. 120, p. S70, 2018.

BHUSHAN, M. et al. Fabrication and a detailed study of antibacterial properties of $\alpha-\mathrm{Fe}_{2} \mathrm{O}_{3} / \mathrm{NiO}$ nanocomposites along with their structural, optical, thermal, magnetic and cytotoxic features. Nanotechnology, v. 30, n. 185101, p. 1-18, 2019.

CAO, Y. et al. Influence of phytochemicals on the biocompatibility of inorganic nanoparticles: a state-of-the-art review. Phytochemistry Reviews, v. 16, n. 3, p. 555-563, 2017.

CHANDRASEKARAN, R. et al. Formulation of Carica papaya latex-functionalized silver nanoparticles for its improved antibacterial and anticancer applications. Journal of Molecular Liquids, v. 219, p. 232-238, 2016.

INCA. Estimativa 2018: Incidência de câncer no Brasil/Instituto Nacional de Câncer. Coordenação de Prevenção e Vigilância. - Rio de Janeiro: INCA, 2017.

KALAIYARASAN, T. et al. One pot green preparation of: Seabuckthorn silver nanoparticles (SBT@) AgNPs) featuring high stability and longevity, antibacterial, antioxidant potential: A nano disinfectant future perspective. RSC Advances, v. 7, n. 81, p. 51130-51141, 2017.

JAMSHIDI-KIA, F. et al. Medicinal plants: Past history and future perspective. Journal of Herbmed Pharmacology, v. 7, n. 1, p. 1-7, 2018.

MANJUMEENA, R. et al. 'Green' biocompatible organic-inorganic hybrid electrospun nanofibers for potential biomedical applications. Journal of Biomaterials Applications, v. 29, n. 7, p. 1039-1055, 2015. 
MEDINA CRUZ, D. et al. Citric juice-mediated synthesis of tellurium nanoparticles with antimicrobial and anticancer properties. Green Chemistry, v. 21, n. 8, p. 1982-1998, 2019.

ORSI, D. et al. New $\mathrm{CeF}_{3}-\mathrm{ZnO}$ nanocomposites for self-lighted photodynamic therapy that block adenocarcinoma cell life cycle. Nanomedicine, v. 13, n.18, p. 2311-2326, 2018.

POOJA, D. et al. Natural polysaccharide functionalized gold nanoparticles as biocompatible drug delivery carrier. International Journal of Biological Macromolecules, v. 80, p. 48-56, 2015.

PRANATHARTHIHARAN, S. et al. Inorganic nanovectors for nucleic acid delivery. Drug Delivery and Translational Research, v. 3, n. 5, p. 446-470, 2013.

$\mathrm{SU}$, H. et al. In vitro evaluation of the toxicity and underlying molecularmechanisms of Janus $\mathrm{Fe}_{3} \mathrm{O}_{4}-\mathrm{TiO}_{2}$ nanoparticles in humanliver cells. Environmental Toxicology, v. 33, n.10, p. 1078-1088, 2018.

WANG, Q. et al. Nanomedicines in Bone Cancer - From Diagnostics to Therapies. Journal of Biomedical Nanotechnology, v. 13, n. 8, p. 911-930, 2017.

YU, J. et al. Induction of programmed necrosis: A novel anti-cancer strategy for natural compounds. Pharmacology \& Therapeutics, v. 214, n. 107593, 2020.

ZHAO, C. et al. Biosynthesis of polyphenols functionalized ZnO nanoparticles: Characterization and their effect on human pancreatic cancer cell line. Journal of Photochemistry and Photobiology B: Biology, v. 183, p. 142-146, 2018. 
